\title{
Isolated complete traumatic avulsion of oculomotor nerve root
}

\author{
Sundeep Malla (10 , ${ }^{1}$ Rebika Dhiman, ${ }^{2}$ Rohit Saxena, ${ }^{3}$ Sanjay Sharma ${ }^{1}$
}

Department of Radiodiagnosis, All India Institute of Medical sciences Delhi, New Delhi, Delhi, India

${ }^{2}$ Dr RP Centre, All India Institute of Ophthalmic Sciences, New Delhi, Delhi, India

${ }^{3} \mathrm{Dr}$ RP Centre, All India Institute for Medical Science, New Delhi, Delhi, India

\section{Correspondence to}

Dr Sanjay Sharma; drssharma@hotmail.com

Accepted 14 April 2020

\section{DESCRIPTION}

A 31-year-old man sustained a road traffic accident. He developed drooping of the eyelid and pupillary dilation with outward deviation of the right eye. Fundus examination was unremarkable. The vision was $6 / 24$ and $6 / 6$ in the right and left eyes, respectively. A post-traumatic right oculomotor nerve injury was suspected. Non-contrast CT of the head done immediately after trauma showed no fracture or brain injury. MRI of the brain was done to localise the site of nerve damage 2 weeks later. It revealed complete avulsion of the right oculomotor nerve from its origin in the brainstem (figure 1). The free end of the avulsed nerve root was seen floating in the interpeduncular cistern. There was no other associated brain injury.

On follow-up at 3 months, patient showed no clinical improvement in ptosis or vision. Post-traumatic oculomotor nerve avulsion is exceedingly rare following head trauma. ${ }^{12}$ Most cases of oculomotor nerve injury are usually documented on postmortem studies. To the best of our knowledge, the antemortem documentation of oculomotor nerve root avulsion has been reported only once before. ${ }^{3}$ Its mechanism is not completely understood, but is believed to be due to shearing injury and differential movements of the intracranial structures during trauma. ${ }^{2}$ Complete avulsion of the nerve root portends a dismal prognosis for the recovery of nerve function. Surgery for strabismus to restore cosmesis is usually the only aim of treatment. The modality of nerve reimplantation at the brainstem is under investigation. ${ }^{3}$

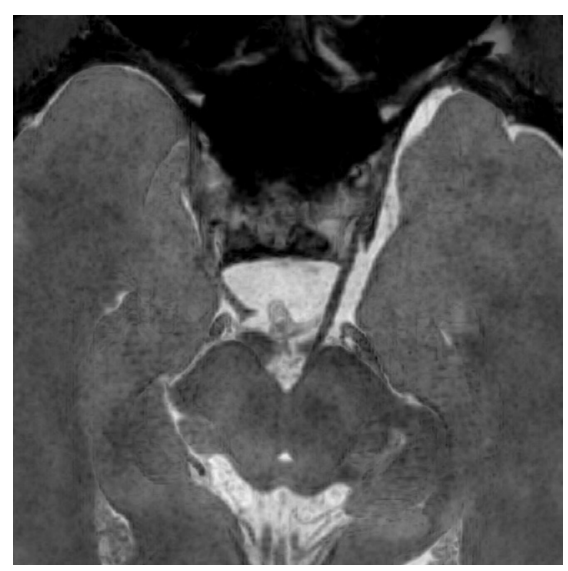

Figure 1 Minimum intensity project image at the level of interpeduncular fossa showing avulsion of the right oculomotor nerve root dangling in the interpeduncular cistern. The normally attached contralateral nerve is also seen.

\section{Patient's perspective}

I had a road traffic accident on the way to work. I suddenly fell down on the road after which I was feeling dizzy. A few minutes later, I was taken to the hospital. In the hospital, I realised that I had a double vision and could not open my right eye. Next day, an eye doctor examined me and suggested an MRI scan. Next day, I was told that the nerve supplying my right eye had torn from its root. I was shocked. Had never heard of something like that before. The eye doctor then reassured me and told that a surgery could be planned to correct the achieve the cosmetic results. The surgery has been planned next year. Hopefully, things will work out for me.

\section{Learning points}

- Isolated oculomotor nerve avulsion is a very rare injury.

- The mechanism of this injury is believed to be shearing injury and differential movements of the intracranial structures during trauma.

- A dedicated thin section MRI for cranial nerve integrity needs to be done in all cases in which there is a suspicion of such injury.

Contributors SM wrote the initial manuscript. SS diagnosed the case and edited the manuscript. RD and RS edited the clinical content.

Funding The authors have not declared a specific grant for this research from any funding agency in the public, commercial or not-for-profit sectors,

Competing interests None declared.

Patient consent for publication Obtained.

Provenance and peer review Not commissioned; externally peer reviewed.

\section{ORCID iD}

Sundeep Malla http://orcid.org/0000-0002-8504-5659

\section{REFERENCES}

1 Kaido T, Tanaka Y, Kanemoto Y, et al. Traumatic oculomotor nerve palsy. J Clin Neurosci Off J Neurosurg Soc Australas 2006;13:852-5.

2 Balcer LJ, Galetta SL, Bagley LJ, et al. Localization of traumatic oculomotor nerve palsy to the midbrain exit site by magnetic resonance imaging. Am J Ophthalmol 1996;122:437-9.

3 Ditta LC, Choudhri AF, Blitz AM, et al. Traumatic avulsion of the oculomotor nerve documented by high-resolution magnetic resonance imaging. J AAPOS Off Publ Am Assoc Pediatr Ophthalmol Strabismus 2015;19:385-7. 
Images in...

Copyright 2020 BMJ Publishing Group. All rights reserved. For permission to reuse any of this content visit https://www.bmj.com/company/products-services/rights-and-licensing/permissions/

BMJ Case Report Fellows may re-use this article for personal use and teaching without any further permission.

Become a Fellow of BMJ Case Reports today and you can:

- Submit as many cases as you like

- Enjoy fast sympathetic peer review and rapid publication of accepted articles

Access all the published articles

Re-use any of the published material for personal use and teaching without further permission

Customer Service

If you have any further queries about your subscription, please contact our customer services team on +44 (0) 2071111105 or via email at support@bmj.com.

Visit casereports.bmj.com for more articles like this and to become a Fellow 